\title{
Plasma total glutathione in humans and its association with demographic and health-related factors
}

\author{
BY ELAINE W. FLAGG ${ }^{1}$, RALPH J. COATES ${ }^{1}$, DEAN P. JONES ${ }^{2}$, \\ J. WILLIAM ELEY ${ }^{1,3}$, ELAINE W. GUNTER ${ }^{4}$, BETHANY JACKSON ${ }^{3}$ \\ AND RAYMOND S. GREENBERG ${ }^{1}$ \\ ${ }^{1}$ Division of Epidemiology, Emory University School of Public Health, Atlanta, Georgia, USA \\ ${ }^{2}$ Department of Biochemistry, Emory University School of Medicine, Atlanta, Georgia, USA \\ ${ }^{3}$ Winship Cancer Center, Emory University School of Medicine, Atlanta, Georgia, USA \\ ${ }^{4}$ Nutritional Biochemistry Branch, Division of Environmental Health Laboratory Sciences, Center \\ for Environmental Health and Injury Control, Centers for Disease Control, Atlanta, Georgia, USA \\ ${ }^{5}$ Department of Nutrition and Family Studies, Andrews University, Berrien Springs, Michigan, USA
}

(Received 15 June 1992 - Accepted 4 January 1993)

\begin{abstract}
The tripeptide glutathione is proposed to be protective against a number of chronic diseases including cardiovascular disease and cancer. However, there have been few studies of plasma glutathione levels in humans and in those studies the numbers of participants have been very small. In an exploratory analysis the determinants of plasma total glutathione (GSH) were investigated in a group of 100 volunteers aged 18-61 years in Atlanta, Georgia, USA during June and July 1989. Data on demographic and healthrelated factors were collected by interview and plasma GSH $_{t}$ was measured using a recently modified laboratory method. The mean concentration of plasma $\mathrm{GSH}_{\mathrm{t}}$ for all 100 participants was $761 \mu \mathrm{g} / \mathrm{l}$, with a standard deviation of $451 \mu \mathrm{g} / \mathrm{l}$, a range of $86-2889 \mu \mathrm{g} / \mathrm{l}$ and a median of $649 \mu \mathrm{g} / \mathrm{l}$. Men had significantly higher levels of plasma $\mathrm{GSH}_{\mathrm{t}}$ than women $(924$ v. $692 \mu \mathrm{g} / \mathrm{l} ; P=0.006)$. Seventh-day Adventists participating in the present study had higher plasma GSH, levels than other subgroups defined by race and/or religion. Among Seventh-day Adventists consumption of a vegetarian diet was associated with increased plasma GSH $_{t}$ concentration $(P=0.002)$. Plasma GSH $_{t}$ levels also appeared to vary by race, but relationships with race could not be clearly disassociated from relationships with religion. Among white participants plasma GSH $_{t}$ concentration decreased with age in women but increased with age in men $(P=0.05)$. Few other factors were associated with plasma $\mathrm{GSH}_{\mathrm{t}}$ concentration, although use of oral contraceptives $(P=0 \cdot 10)$ was somewhat associated with decreased plasma GSH, levels. These findings suggest that plasma GSH, levels may vary with several demographic and health-related attributes and support the need for further research on this potentially important disease-preventive compound.
\end{abstract}

Plasma glutathione: Disease prevention: Humans

The tripeptide glutathione plays a central role in preventing cellular injury and mutation (Cerutti, 1985; Wefers \& Sies, 1988; Stevens \& Jones, 1989; Bendich, 1990) and may be a protective factor in cancer and aging (Ames, 1983; Cross et al. 1987), cardiovascular disease (Cross et al. 1987) and the immune dysfunction of HIV infection (Buhl et al. 1989). Although all mammalian cells are capable of glutathione synthesis (Meister, 1989), the liver is the major source of plasma glutathione (Lauterburg et al. 1984a) and orally administered glutathione increases plasma glutathione concentrations both in animals (Hagen et al. 1990; Aw et al. 1991) and in humans (Hagen \& Jones, 1989). Since epithelial cells are capable of glutathione uptake from plasma (Shan et al. 1990; Aw et al. 
1991), it is possible that people with higher plasma concentrations are at reduced risk of a number of chronic diseases, including epithelial cell cancers. Despite this potential importance there have been few studies characterizing plasma glutathione concentration in healthy humans and sample sizes have been limited to between five and thirty subjects (Owens \& Belcher, 1965; Hagenfeldt et al. 1978; Wendel \& Cikryt, 1980; Chawla et al. 1984; Lauterburg et al. 1984 b; Beutler \& Gelbart, 1985; Burgunder \& Lauterburg, 1986; Buhl et al. 1989; Hagen \& Jones, 1989). Because of the limited information available and the potential importance of plasma glutathione in disease prevention, we undertook an exploratory study to describe its association with demographic and health-related characteristics in a diverse group of 100 healthy human volunteers.

\section{METHODS}

\section{Selection of study participants}

Study participants were recruited primarily from among students, faculty and staff of the Emory University School of Medicine, the American Cancer Society and the US Centers for Disease Control. Because Seventh-day Adventists have been found to be at reduced risk of several cancers and other chronic diseases (Phillips, 1975; Phillips et al. 1978) and because they tend to differ from the general population with regard to diet and other health-related characteristics (Phillips, 1975; Beeson et al. 1989), subjects were also recruited from an Atlanta area Seventh-day Adventist congregation. Current smokers were excluded because smoking appears to modify relationships between serum nutrients and dietary factors (Hunter, 1990). Individuals with major illnesses or taking medication which could potentially affect serum or plasma nutrient levels were also excluded from the study. Medication resulting in exclusion included antibiotics, prednisone, cortisone and medication for conditions such as gout, diabetes, hypertension and high serum cholesterol, Interviewing and blood collection took place between 7 June, 1989 and 31 July, 1989.

A total of 131 eligible people volunteered to participate in the study. Plasma total glutathione $\left(\mathrm{GSH}_{t}\right)$ analyses were completed on 123 of these respondents. Twenty-three plasma $\mathrm{GSH}_{\mathrm{t}}$ values were excluded due to sample deterioration or suspected haemolysis from visual inspection of the plasma sample. Participants excluded from these analyses did not differ by race, sex or age from those included. The analyses presented here were conducted, therefore, using data from the 100 volunteers with completed interviews and valid plasma $\mathrm{GSH}_{\mathrm{t}}$ measurements.

\section{Interview data}

After informed consent was obtained, information about health risk factors was collected by personal interview using the Health Habits and History Questionnaire (HHHQ) developed by Block and colleagues (Block, 1989) at the US National Institutes of Health. The HHHQ was developed and validated for epidemiological studies of diet, health-related factors and cancer. Demographic information obtained included the respondent's age, race, sex, marital status, education level and employment status. Data were also collected on a number of health-related characteristics such as former use of cigarettes, current consumption of alcohol, usual amount of sleep and exercise, current use of medication and current or past medical conditions. Trained interviewers used a computerized version of the questionnaire to enter the self-reported responses directly into a personal computer.

Immediately after completion of the interview a non-fasting blood sample was collected from the study participants. Blood collection was obtained by routine venepuncture, using a 19 gauge butterfly needle to avoid haemolysis. Valid sampling for glutathione requires that haemolysis be avoided because erythrocytes contain large amounts of glutathione that does 
Table 1. Demographic characteristics of the study participants

\begin{tabular}{|c|c|c|c|c|}
\hline \multirow{2}{*}{$\begin{array}{l}\text { Demographic } \\
\text { characteristic }\end{array}$} & \multicolumn{2}{|c|}{ Men } & \multicolumn{2}{|c|}{ Women } \\
\hline & $n$ & $\%$ total & $n$ & $\%$ total \\
\hline Total & 30 & $100 \cdot 0$ & 70 & $100 \cdot 0$ \\
\hline \multicolumn{5}{|l|}{ Age category (years) } \\
\hline $18-29$ & 13 & $43 \cdot 3$ & 21 & $30 \cdot 0$ \\
\hline $30-39$ & 7 & $23 \cdot 3$ & 24 & $34 \cdot 3$ \\
\hline $40-61$ & 10 & $33 \cdot 3$ & 25 & $35 \cdot 7$ \\
\hline \multicolumn{5}{|l|}{ Race } \\
\hline White & 23 & 76.7 & 49 & $70 \cdot 0$ \\
\hline Non-white* & 7 & $23 \cdot 3$ & 21 & $30 \cdot 0$ \\
\hline \multicolumn{5}{|l|}{ Seventh-day } \\
\hline \multicolumn{5}{|l|}{ Adventist } \\
\hline No & 27 & $90 \cdot 0$ & 61 & $87 \cdot 1$ \\
\hline Yes & 3 & $10 \cdot 0$ & 9 & $12 \cdot 9$ \\
\hline \multicolumn{5}{|l|}{ Education level } \\
\hline High School & 1 & $3 \cdot 3$ & 8 & $11 \cdot 4$ \\
\hline College & 5 & $16 \cdot 7$ & 27 & $38 \cdot 6$ \\
\hline Advanced degree & 24 & $80 \cdot 0$ & 35 & $50 \cdot 0$ \\
\hline \multicolumn{5}{|l|}{ Employment status } \\
\hline Employed & 21 & $70 \cdot 0$ & 57 & $81 \cdot 4$ \\
\hline Student & 7 & $23 \cdot 3$ & 11 & $15 \cdot 7$ \\
\hline Other ${ }^{\dagger}$ & 2 & 6.7 & 2 & $2 \cdot 9$ \\
\hline
\end{tabular}

* Includes black (three men, seventeen women), hispanic (one man), and asian (three men, four women) races.

$\dagger$ Includes retired (one man), unemployed (one man, one woman), and homemakers (one woman).

not readily exchange with the extracellular pool and, thus, may not be available for utilization by other tissues (Lash \& Jones, 1985).

\section{Laboratory analyses}

For the present study we measured plasma $\mathrm{GSH}_{t}$, a mixture of reduced glutathione and all disulphide forms. To obtain these measurements a $2 \mathrm{ml}$ blood specimen was collected into a tube containing $100 \mu \mathrm{l}$ heparin $(2 \mathrm{mg} / \mathrm{ml})$ in normal saline $(9 \mathrm{~g} \mathrm{NaCl} / 1)$ to prevent coagulation and $400 \mu \mathrm{l} 10 \mathrm{mM}-1,10$-phenanthroline in normal saline to prevent autooxidation. This tube was immediately centrifuged in a Fisher microcentrifuge for $0.5 \mathrm{~min}$ to obtain plasma. 5 -Sulphosalicylic acid $(100 \mathrm{mg} / \mathrm{ml} ; 250 \mu \mathrm{l})$ was added to $500 \mu \mathrm{l}$ of the plasma supernatant fraction. The tube was then placed on dry ice for transport to the laboratory for analysis.

In the laboratory $50 \mu \mathrm{l} 10 \mathrm{M}-\mathrm{NaOH}$ was added to neutralize the acid and $100 \mu 110 \mathrm{~mm}$ dithiothreitol in $0.1 \mathrm{M}-\mathrm{NaH}_{2} \mathrm{PO}_{4}(\mathrm{pH} 6.0)$ was added to release glutathione from all disulphide forms. After $15 \mathrm{~min}$ of incubation at room temperature, $500 \mu 1$ of a solution of 2 parts methanol and 1 part chloroform was added to remove lipids. The tubes were centrifuged for $2 \mathrm{~min}$ and the aqueous phase was drawn off and treated with $500 \mu 1$ trichloracetic acid $(300 \mathrm{mg} / \mathrm{ml})$ to remove the protein. Following centrifugation for $2 \mathrm{~min}$ the supernatant fraction was drawn off. Iodoacetic acid $(40 \mu \mathrm{M} ; 100 \mu \mathrm{l})$ and $1 \mathrm{M}-\mathrm{KOH}-\mathrm{K}_{2} \mathrm{CO}_{3}(\mathrm{pH} 8.0 ; 150$ $\mu \mathrm{l})$ were added to $500 \mu \mathrm{l}$ supernatant fraction, which was than incubated for $1 \mathrm{~h}$ at room temperature. 1-Fluoro-2,4-dinitrobenzene $(15 \mu \mathrm{l} / \mathrm{ml} ; 500 \mu \mathrm{l})$ in absolute ethanol and $1 \mathrm{M}$ $\mathrm{KOH}-\mathrm{K}_{2} \mathrm{CO}_{3}(\mathrm{pH} 8.0 ; 50 \mu \mathrm{l})$ were added to the supernatant fraction, which was incubated for $4 \mathrm{~h}$ at room temperature. The glutathione derivative was determined by the HPLC method of Reed et al. (1980), with minor modifications by Lash \& Jones (1985). 


\section{Statistical analyses}

The overall distribution of plasma $\mathrm{GSH}_{\mathrm{t}}$ was characterized in the study participants by calculating the mean, standard deviation, median and range of values for all 100 subjects. To determine whether the plasma $\mathrm{GSH}_{\mathrm{t}}$ concentration was normally distributed the data were plotted in a normal probability plot (Neter et al. 1985) and a Kolmogorov-Smirnov goodness of fit D statistic was calculated (Zar, 1984). Because the distribution of plasma $\mathrm{GSH}_{\mathrm{t}}$ concentration was skewed the values were $\log _{\mathrm{e}}$-transformed to produce normally distributed data for further analyses.

In order to compare plasma $\mathrm{GSH}_{\mathrm{t}}$ concentrations among study subgroups defined by the demographic and health-related characteristics of interest, mean values for the subgroups were calculated using $\log _{\mathrm{e}}$-transformed data. Because the study participants were volunteers, and, therefore, cannot be assumed to represent the population from which they were drawn, statistical tests and $95 \%$ confidence intervals for subgroup means were based on the mean square error (MSE) from analysis of variance (ANOVA) for unbalanced data, which gives equal importance to all analysis subgroups (Neter et al. 1985). Geometric means for these subgroups and associated upper and lower $95 \%$ confidence bounds were calculated by taking the antilogs of $\log _{\mathrm{e}}$-transformed data (Flanders et al. 1992).

The sex- and/or age-adjusted associations between demographic and health-related characteristics and plasma $\mathrm{GSH}_{t}$ concentration were examined using linear-regression models which incorporated indicator variables for the factors of interest as well as sex and/or age indicators (Neter et al. 1985). Factor level (i.e. subgroup) means with their standard errors were calculated using the variance-covariance matrix values and beta parameter estimates from the best fitting linear-regression model and substituting the entire group's means for sex and/or age variables in the $\mathrm{X}$ matrix of constants. Confidence intervals $(95 \%)$ about adjusted factor level means were calculated using adjusted standard errors.

Statistical significances of differences between geometric means were determined by taking differences between means from $\log _{\mathrm{e}}$-transformed data and calculating the standard errors of the differences based on the MSE. Subgroup comparisons which were adjusted for sex and/or age category were similarly obtained using adjusted means and adjusted standard errors. Bonferroni and Tukey procedures were used to correct for multiple comparisons (Neter et al. 1985).

RESULTS

The study participants were predominantly female, white, under the age of 40 years, welleducated and employed (Table 1). There was little difference between men and women except that men in the present study had higher levels of education $(P=0.02)$, and women were somewhat more likely to be single, divorced, widowed or separated $(P=0 \cdot 16)$. Relatively few Seventh-day Adventists participated in the present study.

For the 100 participants the mean plasma $\mathrm{GSH}_{\mathrm{t}}$ concentration was $761 \mu \mathrm{g} / 1$ with a standard deviation of $451 \mu \mathrm{g} / \mathrm{l}$. Plasma $\mathrm{GSH}_{t}$ levels ranged from 86 to $2889 \mu \mathrm{g} / 1$ with a median value of $649 \mu \mathrm{g} / 1$. For men the mean plasma $\mathrm{GSH}_{\mathrm{t}}$ concentration was $924 \mu \mathrm{g} / \mathrm{l}$, while for women the mean was $692 \mu \mathrm{g} / 1(P=0 \cdot 006)$. Differences in plasma $\mathrm{GSH}_{\mathrm{t}}$ level by race and by Seventh-day Adventist status could not be evaluated completely because all Seventh-day Adventists included in the present study were black, and because no black men participated in the present study who were not Seventh-day Adventists. Comparisons were made, therefore, among selected subgroups using the MSE based on all sample observations (Neter et al. 1985). Among men and women, Seventh-day Adventists had higher plasma $\mathrm{GSH}_{\mathrm{t}}$ levels than did other race/religion subgroups. Among black women, Seventh-day Adventists were found to have much higher levels of plasma $\mathrm{GSH}_{t}$ than non-Seventh-day 
Table 2. Mean plasma total glutathione $\left(G S H_{t}\right)$ concentration of the study participants, by race/Seventh-day Adventist (SDA) status and sex*

\begin{tabular}{|c|c|c|c|c|c|c|c|c|}
\hline & \multicolumn{8}{|c|}{ Plasma GSH $(\mu \mathrm{g} / 1)$} \\
\hline & \multicolumn{4}{|c|}{ Men } & \multicolumn{4}{|c|}{ Women } \\
\hline & $n$ & Mean & $\begin{array}{l}\text { Geometric } \\
\text { mean }\end{array}$ & $\begin{array}{c}95 \% \mathrm{CI} \text { for } \\
\text { geometric } \\
\text { mean }\end{array}$ & $n$ & Mean & $\begin{array}{l}\text { Geometric } \\
\text { mean }\end{array}$ & $\begin{array}{c}95 \% \text { CI for } \\
\text { geometric } \\
\text { mean }\end{array}$ \\
\hline Black SDA & 3 & 1479 & 1301 & $736-2298$ & 9 & 983 & 923 & $665-1282$ \\
\hline Other Non-SDA $\dagger$ & 4 & 1099 & 1092 & $667-1787$ & 4 & 873 & 772 & $471-1263$ \\
\hline White Non-SDA & 23 & 822 & 745 & $606-914$ & 49 & 668 & 573 & $498-660$ \\
\hline Black Non-SDA & 0 & - & $\ldots$ & - & 8 & 420 & 397 & $280-562$ \\
\hline Total & 30 & 924 & 829 & $682-1006$ & 70 & 692 & 594 & $524-675$ \\
\hline
\end{tabular}

CI, confidence intervals.

* For details of procedures, see pp. 798-800.

$\dagger$ Includes Hispanic (one man) and Asian (three men, four women) races.

Table 3. Mean plasma total glutathione $\left(G S H_{t}\right)$ concentration by dietary status for black Seventh-day Adventists among the study participants*

\begin{tabular}{llccc}
\hline \hline & & \multicolumn{3}{c}{ Plasma GSH $_{\mathrm{t}}(\mu \mathrm{g} / \mathrm{l})$} \\
\cline { 3 - 5 } & $n$ & Mean & $\begin{array}{c}\text { Adjusted } \\
\text { geometric mean }\end{array}$ & $\begin{array}{c}95 \% \mathrm{CI} \text { for } \\
\text { adjusted } \dagger \\
\text { geometric mean }\end{array}$ \\
\hline Vegetarian & 6 & 1440 & 1388 & $(1127-1710)$ \\
Non-vegetarian & 6 & 773 & 728 & $(591-897)$ \\
\hline
\end{tabular}

CI, confidence intervals.

* For details of procedures, see pp. 798-800.

$\dagger$ Adjusted for sex.

Adventists ( $P=0.003$; Table 2$)$. White non-Seventh-day Adventist women tended to have higher concentrations of plasma $\mathrm{GSH}_{t}$ than did black non-Seventh-day Adventist women $(P=0 \cdot 16)$. Among whites only, plasma $\mathrm{GSH}_{\mathrm{t}}$ levels were somewhat higher for men than for women $(P=0 \cdot 12)$.

Too few whites and non-Seventh-day Adventists consumed a vegetarian diet for a complete analysis of this factor among all study participants. However, among the twelve Seventh-day Adventists participating in the present study, half consumed a vegetarian diet. When adjusted for sex, Seventh-day Adventists on a vegetarian diet had higher levels of plasma $\mathrm{GSH}_{\mathrm{t}}$ than Seventh-day Adventists who were not vegetarians ( $P=0.002$; Table 3 ).

Because of the heterogeneity of relationships between plasma $\mathrm{GSH}_{\mathrm{t}}$ concentration and race/Seventh-day Adventist status, and because of the small number of non-white men in the present study, further analyses were restricted to data collected on whites only.

The relationship between age and plasma $\mathrm{GSH}_{\mathrm{t}}$ concentration appeared to be modified by sex. Plasma $\mathrm{GSH}_{\mathrm{t}}$ levels increased with age in men but declined with advancing age in women (sex $\times$ age $P=0.05$; Table 4). There was essentially no variation in plasma $\mathrm{GSH}_{\mathrm{t}}$ levels among groups defined by the demographic characteristics of marital status, education and employment status (values not shown). 
Table 4. Mean plasma total glutathione $\left(G S H_{t}\right)$ concentration for white men and women among the study participants, by age and sex*

\begin{tabular}{|c|c|c|c|c|c|c|c|c|}
\hline \multirow[b]{3}{*}{$\begin{array}{l}\text { Age category } \\
\text { (years) }\end{array}$} & \multicolumn{8}{|c|}{ Plasma $\mathrm{GSH}_{\mathrm{t}}(\mu \mathrm{g} / 1)$} \\
\hline & \multicolumn{4}{|c|}{ Men } & \multicolumn{4}{|c|}{ Women } \\
\hline & $n$ & Mean & $\begin{array}{c}\text { Geometric } \\
\text { mean }\end{array}$ & $\begin{array}{c}95 \% \text { Cl for } \\
\text { geometric } \\
\text { mean }\end{array}$ & $n$ & Mean & $\begin{array}{l}\text { Geometric } \\
\text { mean }\end{array}$ & $\begin{array}{c}95 \% \text { CI for } \\
\text { geometric } \\
\text { mean }\end{array}$ \\
\hline $19-29$ & 8 & 630 & 596 & $417-852$ & 15 & 862 & 721 & $555-936$ \\
\hline $30-39$ & 7 & 881 & 783 & $534-1148$ & 15 & 596 & 505 & $389-656$ \\
\hline $40-58$ & 8 & 961 & 890 & $623-1273$ & 19 & 571 & 529 & $420-668$ \\
\hline
\end{tabular}

CI, confidence intervals.

* For details of procedures, see pp. 798-800.

Table 5. Mean plasma total glutathione $\left(G_{S} H_{t}\right)$ concentration among white study participants, by health conditions and health practices*

\begin{tabular}{|c|c|c|c|c|}
\hline & \multicolumn{4}{|c|}{ Plasma GSH $_{t}(\mu \mathrm{g} / 1)$} \\
\hline & $n$ & Mean & $\begin{array}{l}\text { Adjusted } \uparrow \\
\text { geometric mean }\end{array}$ & $\begin{array}{c}95 \% \mathrm{CI} \text { for } \\
\text { adjusted } \uparrow \\
\text { geometric mean }\end{array}$ \\
\hline \multicolumn{5}{|c|}{ Former cigarette smoker $\ddagger$} \\
\hline No & 36 & 711 & 565 & $470-680$ \\
\hline Yes & 13 & 548 & 596 & $432-822$ \\
\hline \multicolumn{5}{|c|}{$\begin{array}{l}\text { Currently taking oral } \\
\text { contraceptives } \$\end{array}$} \\
\hline No & 18 & 871 & 747 & $580-961$ \\
\hline Yes & 3 & 462 & 417 & $225-773$ \\
\hline \multicolumn{5}{|l|}{ Body mass index $\|$} \\
\hline Normal & 58 & 725 & 616 & $538-706$ \\
\hline Overweight & 14 & 681 & 654 & $496-864$ \\
\hline \multicolumn{5}{|l|}{ Takes vitamins } \\
\hline No & 30 & 823 & 718 & $596-865$ \\
\hline Yes: Irregular & 21 & 558 & 501 & $401-625$ \\
\hline Regularly & 21 & 724 & 634 & $510-788$ \\
\hline \multicolumn{5}{|l|}{ Consumes alcohol } \\
\hline Never & 8 & 610 & 604 & $420-869$ \\
\hline Yes, Ever & 64 & 730 & 626 & $552-709$ \\
\hline \multicolumn{5}{|l|}{ Usual exercise } \\
\hline $\begin{array}{l}\text { More than once } \\
\text { weekly }\end{array}$ & 30 & 854 & 710 & $591-854$ \\
\hline Once weekly & 9 & 550 & 502 & $360-700$ \\
\hline $\begin{array}{l}\text { Less than once } \\
\text { weekly }\end{array}$ & 33 & 637 & 587 & $490-704$ \\
\hline
\end{tabular}

CI, confidence intervals.

* For details of participants and procedures, see pp. 798-800.

$\uparrow$ Geometric means adjusted for sex and age in two categories (18-34 years and 35 years or older). For analyses restricted to a single sex, adjustment is for age only.

$\$$ Among women, since only one man was a former cigarette smoker.

$\S$ Among women aged 18-34 years only. The geometric mean is unadjusted.

$\|$ (weight $(\mathrm{kg})) /(\text { height }(\mathrm{m}))^{2}$. Overweight $=\mathrm{BMI} \geqslant 27 \cdot 8$, men and $\mathrm{BMI} \geqslant 27 \cdot 3$, women.

I Includes consumption of beer, wine or spirits. 
Table 6. Mean plasma total glutathione $\left(G S H_{t}\right)$ concentration among white study participants, by time interval between last meal and blood sampling and by time of day the blood sample was withdrawn*

\begin{tabular}{|c|c|c|c|c|}
\hline & \multicolumn{4}{|c|}{ Plasma GSH $_{\mathfrak{t}}(\mu \mathrm{g} / 1)$} \\
\hline & $n$ & Mean & $\begin{array}{c}\text { Adjusted } \uparrow \\
\text { geometric mean }\end{array}$ & $\begin{array}{c}95 \% \mathrm{CI} \\
\text { adjusted } \uparrow \\
\text { geometric mean }\end{array}$ \\
\hline \multicolumn{5}{|c|}{$\begin{array}{l}\text { Time interval between last } \\
\text { meal and blood sampling }\end{array}$} \\
\hline $0-1 \mathrm{~h} 59 \mathrm{~min}$ & 13 & 638 & 590 & $444-783$ \\
\hline $2-3 \mathrm{~h} 59 \mathrm{~min}$ & 34 & 695 & 584 & $489-696$ \\
\hline $4-5 \mathrm{~h} 59 \mathrm{~min}$ & 15 & 796 & 708 & $542-924$ \\
\hline $\begin{array}{l}6+\mathrm{h} \\
\text { Time of day } \\
\text { (hours) }\end{array}$ & 9 & 813 & 713 & $503-1010$ \\
\hline $09 \cdot 30-11 \cdot 29$ & 31 & 666 & 578 & $485-690$ \\
\hline $11 \cdot 30-13 \cdot 29$ & 17 & 748 & 691 & $544-876$ \\
\hline $13 \cdot 30-15 \cdot 29$ & 11 & 889 & 822 & $609-1109$ \\
\hline $15 \cdot 30-17 \cdot 30$ & 13 & 652 & 527 & $395-704$ \\
\hline
\end{tabular}

$\mathrm{Cl}$, confidence intervals.

* For details of participants and procedures, see pp. 798-800.

$\dagger$ Geometric means adjusted for sex and age in two categories (18-34 years and 35 years or older).

There was little variation in plasma $\mathrm{GSH}_{\mathrm{t}}$ levels by other health characteristics and practices (Table 5). Among women, former use of cigarettes was not associated with plasma $\mathrm{GSH}_{t}$ level $(P=0.79)$. In women under 35 years, oral contraceptive users appeared to have lower levels of plasma $\mathrm{GSH}_{\mathrm{t}}(P=0 \cdot 10)$. Body mass index $(P=0 \cdot 80)$ and usual level of exercise $(P=0 \cdot 40)$ were unrelated to plasma $\mathrm{GSH}_{\mathrm{t}}$ concentration. Participants who consumed vitamins on an irregular basis had lower plasma $\mathrm{GSH}_{t}$ levels than non-users and regular vitamin consumers $(P=0.07)$, but this affect did not appear to be consistent across all sex and age categories (category-specific data not shown). Alcohol consumers did not have reduced levels of plasma $\mathrm{GSH}_{\mathrm{t}}(P=0 \cdot 54)$. Other health-related factors which appeared unrelated to plasma $\mathrm{GSH}_{t}$ concentration included usual amount of sleep, family history of cancer, and current minor medical conditions such as asthma or hay fever (values not shown).

Two other factors which were evaluated in relation to plasma $\mathrm{GSH}_{\mathrm{t}}$ levels were timeinterval elapsed between last meal and blood sampling, and the time of day the blood sample was withdrawn (Table 6). Plasma $\mathrm{GSH}_{t}$ level varied little by either factor $(P>0.50)$. Although plasma $\mathrm{GSH}_{\mathrm{t}}$ concentration appeared to increase somewhat with increasing duration between last meal and blood sampling, confidence intervals about the sex- and age-adjusted geometric means overlapped widely. There was no apparent trend or difference in mean plasma $\mathrm{GSH}_{t}$ level with time of day the blood collection took place, although plasma $\mathrm{GSH}_{\mathrm{t}}$ concentrations were somewhat higher in the early afternoon.

\section{DISCUSSION}

In the present exploratory study of 100 healthy volunteers we found a wide range of plasma $\mathrm{GSH}_{\mathrm{t}}$ levels which appeared to vary by sex, age, and possibly by race. In addition, Seventhday Adventists had higher levels of plasma $\mathrm{GSH}_{t}$ than did non-Seventh-day Adventists, 
while among Seventh-day Adventists vegetarians appeared to have the highest concentrations of plasma $\mathrm{GSH}_{\mathrm{t}}$.

Glutathione may be important in disease prevention because of its role in preventing cellular injury and mutation by detoxifying xenobiotics (Stevens \& Jones, 1989) and by protecting cells against oxidative damage, both directly as an antioxidant (Cerutti, 1985) and indirectly by maintaining other cellular antioxidants in a functional state (Wefers \& Sies, 1988; Bendich, 1990). In addition, a number of studies indicate that glutathione may be involved in various aspects of the immune response, including T-cell and lymphocyte activation and proliferation (Hamilos \& Wedner, 1985; Droge et al. 1986).

Although no prospective studies have examined the relationship between plasma glutathione status and disease risk, it has been shown that alcoholic subjects (Chawla et al. 1984; Lauterburg et al. 1984 b), patients with malignancies (Beutler \& Gelbart, 1985), HIVseropositive individuals (Buhl et al. 1989) and those ingesting acetaminophen (Lauterburg et al. 1984 b; Beutler \& Gelbart, 1985) or diets deficient in ascorbic acid (Henning et al. 1991) have lower levels of plasma glutathione than do healthy subjects.

Plasma $\mathrm{GSH}_{\mathrm{t}}$ levels were consistent with values reported in previous smaller studies of healthy humans. In those studies the mean values of plasma glutathione vary considerably, ranging from 104 to $5465 \mu \mathrm{g} / 1$ (Owens \& Belcher, 1965; Hagenfeldt et al. 1978; Wendel \& Cikryt, 1980; Chawla et al. 1984; Lauterburg et al. 1984b; Beutler \& Gelbert, 1985; Burgunder \& Lauterburg, 1986; Buhl et al. 1989; Hagen \& Jones, 1989). This wide variation between studies may be due principally to differences in the forms of glutathione that were measured and in the laboratory methods used. In addition, because the concentration of glutathione in erythrocytes is much greater than in plasma (Beutler \& Gelbart, 1985; Lash \& Jones, 1985), small amounts of haemolysis can result in artifactually high plasma glutathione levels. For the present report all plasma samples with apparent haemolysis were excluded from the analyses.

In the present study men had much higher levels of plasma $\mathrm{GSH}_{\mathrm{t}}$ than women. Studies of mice have demonstrated significantly higher levels of plasma glutathione in males than in females (Hirayama et al. 1987; Taniguchi et al. 1989), although this association has not been found in rats (Taniguchi et al. 1989). Two previous studies in humans, each with thirty participants, did not report a difference in plasma glutathione concentrations between men and women (Wendel \& Cikryt, 1980; Beutler \& Gelbart, 1985). Reasons for differences in glutathione levels by sex are not well understood, but research with animals indicates that plasma glutathione level may be affected by sex hormones. In mice the turnover rates of hepatic and renal glutathione appear to be significantly faster in males compared with females, with male castration decreasing these rates to levels approaching those of females. Several researchers have proposed therefore, that glutathione metabolism, secretion and transport may be influenced by sex hormones (Hirayama et al. 1987; Taniguchi et al. 1989). We found that, among young women, use of oestrogen-containing oral contraceptives was associated with lower plasma $\mathrm{GSH}_{t}$ levels, suggesting that the relationship between hormonal status, sex and plasma $\mathrm{GSH}_{\mathrm{t}}$ concentration may be complex in humans. We could identify no other likely explanations for the observed difference in plasma $\mathrm{GSH}_{\mathrm{t}}$ by sex. Men and women in the present study were similar in most characteristics except education and marital status, and plasma $\mathrm{GSH}_{\mathrm{t}}$ concentration was not associated with those factors.

Among whites the association between age and plasma $\mathrm{GSH}_{\mathrm{t}}$ concentration appeared to be modified by sex. Several studies of mice have demonstrated that tissue glutathione concentrations decline with age (Hazelton \& Lang, 1980; Stohs et al. 1982), but sex-specific comparisons were not presented. The two previous studies in humans which examined sex differences in plasma glutathione concentration did not look at the combined effect of age 
and sex (Wendel \& Cikryt, 1980; Beutler \& Gelbart, 1985), although one study reported no overall relationship between plasma glutathione level and age (Beutler \& Gelbart, 1985). We know of no other nutritional biochemical measures that vary by age and sex in this manner and do not know why age might influence plasma $\mathrm{GSH}_{\mathrm{t}}$ levels differently in men and women. This relationship should be considered in future studies of plasma glutathione in humans.

Plasma $\mathrm{GSH}_{\mathrm{t}}$ concentration appeared to vary substantially by race and/or membership in the Seventh-day Adventist church, although we could not distinguish clearly between these factors. Diet may account partially for this relationship, as the Seventh-day Adventist religion endorses adherence to a lacto-ovovegetarian diet and other dietary restrictions (Phillips, 1975; Beeson et al. 1989). The Seventh-day Adventists participating in the present study who consumed vegetarian diets had much higher levels of plasma $\mathrm{GSH}_{t}$ than nonvegetarian Seventh-day Adventists. Although this comparison was based on small numbers of subjects in each group, the difference in mean plasma $\mathrm{GSH}_{t}$ concentration between these two groups was striking.

Diet may affect plasma glutathione level in a number of ways. In rodents, diets low in the glutathione-precursor amino acids methionine and cysteine have been shown to decrease hepatic glutathione concentration (Sendelbach et al. 1990) while a cysteine-rich diet increases liver glutathione levels (Bounous et al. 1989). Hepatic glutathione concentration has been found to decrease in riboflavin-deficient rats (Taniguchi et al. 1989). Although GSH is synthesized endogenously from its precursor amino acids (Meister, 1989), animal studies have shown that exogenous glutathione is transported into the cells of the small intestine as an intact tripeptide (Hagen \& Jones, 1987). Orally administered glutathione increases plasma glutathione levels in rats (Hagen et al. 1990; Aw et al. 1991) and in humans (Hagen \& Jones, 1989).

Dietary glutathione is available from a variety of food sources. Meats contain the highest concentrations, with large amounts in fruits and vegetables and little or none in grains and dairy products (Jones et al. 1992). Thus, differences in diet may explain some differences in plasma levels. However, because of the relatively high concentrations of glutathione and its precursor amino acids in meats (Jones et al. 1992), it is uncertain that vegetarian Seventhday Adventists consume more glutathione precursor amino acids or more intact glutathione. To our knowledge, no studies in humans have yet examined the relationship between diet and plasma glutathione concentration.

Other more complex dietary or health-related factors may affect plasma glutathione levels. In the present study participants who took vitamins irregularly appeared to have lower levels of plasma $\mathrm{GSH}_{\mathrm{t}}$ than those not taking any vitamins or taking vitamins on a regular basis. This effect, however, was not consistent across all sex and age categories examined, and may be spurious or due to other lifestyle factors associated with irregular vitamin usage. Although a recent study of healthy men receiving ascorbic acid-deficient diets demonstrated decreased plasma glutathione levels (Henning et al. 1991), the relationships between the plasma antioxidants ascorbic acid, $\alpha$-tocopherol, $\beta$-carotene and glutathione appear to be quite complex (Wefers \& Sies, 1988; Frei et al. 1989; Bendich, 1990) and it is unclear whether ingestion of vitamins, particularly antioxidants, should theoretically increase or decrease plasma $\mathrm{GSH}_{\mathrm{t}}$ levels.

Among white participants plasma $\mathrm{GSH}_{\mathrm{t}}$ concentration did not vary significantly by either time-interval between last meal and blood sampling, or time of day that the blood sample was taken. However, a slight increasing trend in plasma $\mathrm{GSH}_{\mathrm{t}}$ level was observed with increasing duration between the most recent meal and blood sampling. In rats fasting appears to increase hepatic glutathione synthesis (Lauterburg \& Mitchell, 1981) with a concomitant increase in efflux of the reduced (GSH) and oxidized (GSSG) forms of glutathione (Lauterburg et al. 1984a), and it is possible that a similar phenomenon exists 
in humans. Although diurnal variations in rat blood glutathione levels have been observed, these fluctuations appear to be limited to erythrocyte glutathione (Calcutt, 1967).

Several limitations to the present study should be noted. Although the study is, to our knowledge, the largest conducted to date which examines plasma glutathione concentrations in free-living humans, the numbers of subjects in the analysis subgroups become small with increasing number of simultaneously examined factors. This reduces the statistical power of subgroup comparisons, and for this reason we chose to adjust only for sex and age, the two most important factors associated with plasma $\mathrm{GSH}_{t}$ level.

An additional limitation is that most participants in the present study were recruited from among employees and students in health-related organizations. Other study subjects were members of a Seventh-day Adventist congregation. Both groups of participants are likely to differ from members of the general population on a number of health-related factors. This, along with the self-referred nature of the study participants, precludes generalization of these findings to the population at large.

It is also important to note that in the present study we assayed plasma $\mathrm{GSH}_{t}$, which consists of GSH and all disulphide forms, including mixed disulphides with cysteine and protein. Many previous investigations of plasma glutathione assessed a combination of GSH and GSSG forms of glutathione, but did not assay for the presence of plasma glutathione in the form of mixed disulphides. In rats, however, approximately $70 \%$ of plasma glutathione exists in the protein-bound form (Lash \& Jones, 1985), and recent studies in both rats and humans have shown that, like glutathione, protein-bound glutathione appears to increase in response to orally administered glutathione (Hagen \& Jones, 1989; Aw et al. 1991). Protein-bound glutathione may participate in regulating the biological activity of plasma peptide hormones and immunoglobulins and receptor binding to plasma membranes (Lash \& Jones, 1985). Because of this, plasma $\mathrm{GSH}_{\mathrm{t}}$, which includes the potentially biologically important disulphide forms, was assayed in the present study.

In conclusion, from the present study it is apparent that plasma $\mathrm{GSH}_{t}$ concentrations vary widely in humans and are influenced by sex and age. Because research indicates a vegetarian diet is associated with reduced risk of some chronic diseases (Dwyer, 1988; National Research Council Committee on Diet and Health, 1989) and because Seventh-day Adventists are also at reduced risk of certain chronic diseases (Phillips, 1975; Phillips et al., 1978), it was particularly intriguing that plasma $\mathrm{GSH}_{\mathrm{t}}$ levels were higher among Seventhday Adventists and among vegetarians. Because glutathione has several biological functions that may influence risk of chronic diseases, further studies are needed to examine factors affecting plasma $\mathrm{GSH}_{\mathrm{t}}$ status, particularly dietary practices, and the relationship between plasma $\mathrm{GSH}_{\mathrm{t}}$ and subsequent disease incidence.

This paper is based on dissertation research by Elaine W. Flagg in partial fulfilment of the requirements for the $\mathrm{PhD}$ degree at Emory University and was supported in part by cancer education grant CA17998-15 from the US National Institutes of Health. Dean P. Jones was supported in part by grant HL-39968 from the US National Institutes of Health. J. William Eley is a recipient of an American Cancer Society Career Development Award.

The authors thank Drs W. Dana Flanders and Michael H. Kutner for their advice regarding the analysis of these data.

\section{REFERENCES}

Ames, B. N. (1983). Dietary carcinogens and anticarcinogens. Oxygen radicals and degenerative diseases. Science 221, $1256-1264$.

Aw, T. Y., Wierzbicka, G. \& Jones, D. P. (1991). Oral glutathione increases tissue glutathione in vivo. ChemicoBiological Interactions 80, 89-97.

Beeson, W. L., Mills, P. K., Phillips, R. L., Andress, M. \& Fraser, G. E. (1989). Chronic disease among Seventh- 
day Adventists, a low-risk group. Rationale, methodology, and description of the population. Cancer 64, $570-581$.

Bendich, A. (1990). Antioxidant micronutrients and immune responses. Annals of the New York Academy of Sciences 587, 168-180.

Beutler, E. \& Gelbart, T. (1985). Plasma glutathione in health and in patients with malignant disease. Journal of Laboratory and Clinical Medicine 105, 581-584.

Block, G. (1989). Health Habits and History Questionnaire: Diet History and Other Risk Factors. Personal Computer System Packet. Bethesda, Maryland: Division of Cancer Prevention and Control, US National Cancer Institute, US National Institutes of Health.

Bounous, G., Gervais, F., Amer, V., Batist, G. \& Gold, P. (1989). The influence of dietary whey protein on tissue glutathione and the diseases of aging. Clinical and Investigative Medicine 12, 343-349.

Buhl, R., Holroyd, K. J., Mastrangeli, A., Cantin, A. M., Jaffe, H. A., Wells, F. B., Saltini, C. \& Crystal, R. G (1989). Systemic gluthatione deficiency in symptom-free HIV-seropositive individuals. Lancet ii 12941298.

Burgunder, J. M. \& Lauterburg, B. H. (1986). Plasma kinetics of glutathione (GSH) in man: a non-invasive probe to assess hepatic GSH production. Gastroenterology 90, 1717 Abstr.

Calcutt, G. (1967). Diurnal variations in rat blood glutathione levels. Naturwissenschaften 54, 120.

Cerutti, P. A. (1985). Prooxidant states and tumor promotion. Science 227, 375-381.

Chawla, R. K., Lewis, F. W, Kutner, M. H., Bate, D. M., Roy, R. G. B. \& Rudman, D. (1984). Plasma cysteine, cystine, and glutathione in cirrhosis. Gastroenterology $87,770-776$.

Cross, C. E., Halliwell, B. Borish, E. T., Pryor, W. A., Ames, B. N., Saul, R. L., McCord, J. M. \& Harman, D. (1987). Davis conference. Oxygen radicals and human disease. Annals of Internal Medicine 107, 526-545.

Droge, W., Pottmeyer-Gerber, C., Schmidt, H. \& Nick, S. (1986). Glutathione augments the activation of cytotoxic $\mathrm{T}$ lymphocytes in vivo. Immunobiology 172, 151-156.

Dwyer, J. T. (1988). Health aspects of vegetarian diets. American Journal of Clinical Nutrition 48, 712-738.

Flanders, W. D., DerSimonian, R. \& Freedman, D. S. (1992). Interpretation of linear regression models that include transformations or interaction terms. Annals of Epidemiology 2, 735-744.

Frei, B., England, L. \& Ames, B. N. (1989). Ascorbate is an outstanding antioxidant in human blood plasma. Proceedings of the National Academy of Sciences of the U.S.A. 86, 6377-6381.

Hagen, T. M. \& Jones, D. P. (1987). Transepithelial transport of glutathione in vascularly perfused small intestine of rat. American Journal of Physiology 252, G607-G613.

Hagen, T. M. \& Jones, D. P. (1989). Role of glutathione transport in extrahepatic detoxication. In Glutathione Centennial: Molecular Perspectives and Clinical Implications, pp. 423-433 [Y. Sakamoto, T. Higashi, N. Taniguchi and A. Meister, editors]. San Diego, California: Academic Press.

Hagen, T. M., Wierzbicka, G. T., Sillau, A. H., Bowman, B. B. \& Jones, D. P. (1990). Bioavailability of dietary glutathione: effect on plasma concentration. American Journal of Physiology 259, G524 G529.

Hagenfeldt, L., Arvidsson, A. \& Larsson, A. (1978). Glutathione and gamma-glutamylcysteine in whole blood, plasma and erythrocytes. Clinica Chimica Acta 85, 167-173.

Hamilos, D. L. \& Wedner, H. J. (1985). The role of glutathione in lymphocyte activation. I. Comparison of inhibitory effects of buthionine sulfoximine and 2-cyclohexene-1-one by nuclear size transformation. Journal of Immunology 135, 2740-2747.

Hazelton, G. A. \& Lang, C. A. (1980). Glutathione contents of tissues in the aging mouse. Biochemical Journal 188, 25-30.

Henning. S. M., Zhang, J. Z., McKee, R. W., Swendseid, M. E. \& Jacob, R. A. (1991). Glutathione blood levels and other oxidant defense indices in men fed diets low in vitamin C. Journal of Nutrition 121, 1969-1975.

Hirayama, K., Yasutake, A. \& Inoue, M. (1987). Effect of sex hormones on the fate of methylmercury and on glutathione metabolism in mice. Biochemical Pharmacology 36, 1919-1924.

Hunter, D. (1990). Biochemical indicators of dietary intake. In Nutritional Epidemiology, pp. 143-216 [W. Willett, editor]. New York, NY: Oxford University Press.

Jones, D. P., Coates, R. J., Flagg, E. W., Eley, J. W., Block G., Greenberg, R. S., Gunter, E. W. \& Jackson, B. (1992). Glutathione in foods listed in the National Cancer Institute's health habits and history food frequency questionnaire. Nutrition and Cancer 17, 57-75.

Lash, L. H. \& Jones, D. P. (1985). Distribution of oxidized and reduced forms of glutathione and cysteine in rat plasma. Archives of Biochemistry and Biophysics 240, 583-592.

Lauterburg, B. H., Adams, J. D. \& Mitchell, J. R. (1984a). Hepatic glutathione homeostasis in the rat: efflux accounts for glutathione turnover. Hepatology 4, 586-590.

Lauterburg, B. H. \& Mitchell, J. R. (1981). Regulation of hepatic glutathione turnover in rats in vivo and evidence for kinetic homogeneity of the hepatic glutathione pool. Journal of Clinical Investigation 67, 1415-1424.

Lauterburg, B. H., Velez, M. E. \& Mitchell, J. R. (1984b). Plasma glutathione (GSH) as an index of intrahepatic GSH in man: response to acetaminophen (AP) and chronic ethanol abuse. Hepatology 4, 1051 Abstr.

Meister, A. (1989). Metabolism and function of glutathione. In Glutathione. Chemical, Biochemical, and Medical Aspects, part A, pp. 367-474 [D. Dolphin, O. Avramovic and R. Poulson, editors]. New York, New York: John Wiley and Sons.

National Research Council Committee on Diet and Health (1989). Diet and Health: Implications for Reducing Chronic Disease Risk, pp. 210, 212, 278-279. Washington, D. C.: National Academy Press. 
Neter, J., Wasserman, W. \& Kutner, M. H. (1985). Applied Linear Statistical Models. Regression, Analysis of Variance, and Experimental Designs, 2nd ed. Homewood, Illinois: Richard D. Irwin, Inc.

Owens, C. W. I. \& Belcher, R. V. (1965). A colorimetric micro-method for the determination of glutathione. Biochemical Journal 94, 705-711.

Phillips, R. L. (1975). Role of life-style and dietary habits in risk of cancer among Seventh-day Adventists. Cancer Research 35, 3513-3522.

Phillips, R. L., Lemon, F. R., Beeson, W. L. \& Kuzma, J. W. (1978). Coronary heart disease mortality among Seventh-day Adventists with differing dietary habits: a preliminary report. American Journal of Clinical Nutrition 31, S191-S198.

Reed, D. J., Babson, J. R., Beatty, P. W., Brodie, A. E., Ellis, W. W. \& Potter, D. W. (1980). High-performance liquid chromatography analysis of nanomole levels of glutathione, glutathione disulfide, and related thiols and disulfides. Analytical Biochemistry 106, 55-62.

Sendelbach, L. E., White, C. A., Howell, S., Gregus, Z. \& Klaassen, C. D. (1990). Effect of sulfhydryl-deficient diets on hepatic metallothionein, glutathione, and adenosine $3^{\prime}$-phosphate $5^{\prime}$-phosphosulfate (PAPS) levels in rats. Toxicology and Applied Pharmacology 102, 259-267.

Shan, X., Aw, T. Y. \& Jones, D. P. (1990), Glutathione-dependent protection against oxidative injury. Pharmacology and Therapeutics 47, 61-71.

Stevens, J. L. \& Jones, D. P. (1989). The mercapturic acid pathway: biosynthesis, intermediary metabolism, and physiological disposition. In Glutathione. Chemical, Biochemical, and Medical Aspects, part B, pp. 45-84 [D. Dolphin, O. Avramovic and R. Poulson, editors]. New York, New York: John Wiley and Sons.

Stohs, S. J., Al-Turk, W. A. \& Angle, C. R. (1982). Glutathione S-transferase and glutathione reductase activities in hepatic and extrahepatic tissues of female mice as a function of age. Biochemical Pharmacology 31, 2113-2116.

Taniguchi, M., Hirayama, K., Yamaguchi, K., Tateishi, N. \& Suzuki, M. (1989). Nutritional aspects of glutathione metabolism and function. In Glutathione, Chemical, Biochemical, and Medical Aspects, part B, pp. 645-727 [D. Dolphin, O. Avramovic and R. Poulson, editors]. New York, New York: John Wiley and Sons.

Wefers, H. \& Sies, H. (1988). The protection by ascorbate and glutathione against microsomal lipid peroxidation is dependent on vitamin E. European Journal of Biochemistry 174, 353-357.

Wendel, A. \& Cikryt, P. (1980). The level and half-life of glutathione in human plasma. FEBS Letters 120 , 209-211.

Zar, J. H. (1984). Biostatistical Analysis. 2nd ed. Englewood Cliffs, New Jersey: Prentice-Hall, Inc. 